Indo. J. Chem. Res., 2019, 6(2), 107-114

\title{
STUDI KINETIKA EFEKTIFITAS MINYAK DAUN CENGKEH (Syzigium aromaticum) SEBAGAI ANTIFUNGI Candida albicans
}

\section{Kinetic Studies Effectiveness of Clove Leaf (Syzigium aromaticum) Oil as Antifungal of Candida albicans}

\author{
Rustam Musta*1, Laily Nurliana ${ }^{2}$ \\ ${ }^{1}$ Chemistry Department, Teacher Training dan Education Faculty, Halu Oleo University, \\ ${ }^{2}$ Chemitry Department, Math and Nature Science Faculty, Halu Oleo University, Kendari Kendari \\ Kampus Bumi Tridarma ; Anduonohu Kendari, Southeast Sulawesi, \\ Telp. (0401)391929/Fax.(0401)390496 \\ *Corresponding author, e-mail: rutammusta.fkip@uho.ac.id
}

Received: Nov. 2018 Published: Jan. 2019

\begin{abstract}
Kinetic studies effectiveness clove leaf (Syzigium aromaticum) oil as antifungal Candida albicans have been done. The study have purpose to determine the reaction order, reaction constants $(k)$ and relationship the concentration of clove leaf (Syzigium aromaticum) oil every time $\left(\mathrm{A}_{t}\right)$ with the initial concentration of of clove (Syzigium aromaticum) oil $\left(\mathrm{A}_{\mathrm{o}}\right)$ and time $(\mathrm{t})$ and equipped determination of the minimum concentration of clove leaf (Syzigium aromaticum)oil effective anti-fungus Candida albicans. The results shows the anti-fungal activity clove leaf (Syzigium aromaticum) oil on Candida albicans for each variation of the concentration 100\%, 75\%, $50 \%$ and $25 \%$ are $14.2 \mathrm{~mm}, 12.2 \mathrm{~mm}, 10.8 \mathrm{~mm}$ and $10.4 \mathrm{~mm}$ respectively. Reaction order as antifungal of the clove leaf (Syzigium aromaticum) oil on Candida albicans is 0.2112 with $k=5.0594$. The minimum concentration of clove leaf (Syzigium aromaticum) oil as anti-fungal Candida albicans is $17.86 \%$.
\end{abstract}

Keywords: Kinetic studies, clove leaf oil, Candida Albicans, antifungal, Syzigium aromaticum

\section{PENDAHULUAN}

Cengkeh (Syzygium aromaticum) adalah tanaman asli Indonesia yang semua bagian tanaman ini menghasilkan minyak atsiri, baik dahan, ranting, daun serta bunganya. Hal ini menjadikan tanaman cengkeh sebagai salah satu komoditi ekspor untuk menyuplai kebutuhan minyak atsiri dunia dan karena itu usaha penyulingan minyak cengkeh terus dikembangkan dan mempunyai nilai ekonomis yang tinggi. Secara umum, kandungan utama minyak cengkeh adalah eugenol (70-80\%), yang mempunyai sifat sebagai stimulan, anestetik lokal, karminatif, antiemetik, antiseptik, dan antispasmodik. Eugenol merupakan cairan tak berwarna atau kuning pucat yang bila terkena cahaya matahari berubah menjadi coklat hitam yang berbau spesifik (Putri dkk., 2014).

Daun cengkeh merupakan sumber minyak atsiri yang sudah banyak diisolasi. Penggunaannya sebagai bahan antifungi telah banyak diteliti dengan hasil-hasil yang dilaporkan sangat potensial untuk dikembangkan secara massif. Minyak cengkeh juga diketahui digunakan sebagai antioksidan. Aktifitas antioksidan minyak cengkeh bahkan lebih tinggi jika dibandingkan dengan antioksidan yang terkandung dalam lemon, anggur, dan ketumbar. Minyak cengkeh dilaporkan memiliki kemampuan yang lebih baik dalam menangkal radikal bebas bila dibandingkan dengan 45 jenis minyak atsiri lainnya (Kim et. al., 2011). Adapun aplikasi minyak cengkeh dalam bidang kesehatan dapat digunakan sebagai antistres, antimikroba, antiperadangan, antigiardial, kebutuhan pembiusan, antibisul dan sebagainya (Charles, 2013).

C. albicans merupakan mikroflora normal yang hidup dalam tubuh manusia, namun dapat menjadi patogen saat keseimbangan flora normal seseorang terganggu ataupun pertahanan imunnya menurun (Hasan, 2015). Menurut Bahari (2012) dalam Khafidhoh dkk. (2015) C. albicans merupakan salah satu spesies fungi yang ditemukan pada tubuh orang yang sehat, seperti dimulut, kerongkongan, usus, saluran genital, feses, dibawah kuku dan kulit. $C$. albicans menimbulkan suatu keadaan yang disebut dengan kandidiasis yaitu penyakit pada mulut, selaput lendir, saluran pencernaan, 


\section{Rustam Musta dkk. / Indo. J. Chem. Res., 2019, 6(2), 107-114}

saluran pernafasan dan saluran gemital terutama pada wanita (Pelezar dan Chan, 2007). Kandidiasis adalah infeksi dari genus Candida terutama C. albicans. Lebih dari 150 spesies Candida telah teridentifikasi dan $70 \%$ kandidiasis disebabkan oleh $C$. albicans. Kandidiasis pada penyakit sistemik menyebabkan peningkatan angka kematian sekitar 71\%-79\% (Hasan, 2015).

Adanya kandungan senyawa fenolik maka minyak daun cengkeh berpotensi untuk dikembangkan sebagai antijamur. Hal ini sesuai dengan penelitian yang pernah dilakukan oleh Widyaningrum dan Try, (2015) tentang senyawa fenol yang terdapat dalam daun sidaguri (Sida rhombifolia) sebagai antijamur $C$. albicans yang ditandai dengan terbentuknya zona bening. Salni dkk. (2013) melakukan penelitian tentang senyawa fenol yang terdapat dalam rimpang lengkuas putih yang dapat menghambat pertumbuhan jamur $C$. albicans dengan zona bening maksimal yang terbentuk $21,67 \mathrm{~mm}$ pada konsentrasi $10 \%$.

Kinetika kimia adalah suatu bidang ilmu kimia yang mempelajari rekasi kimia untuk hubungan konsentrasi pereaksi dengan waktu (Triyono dkk., 1998). Hal ini berarti bahwa dengan menggunakan pendekatan kinetika kimia akan diperoleh orde reaksi dan tetapannya, juga akan diketahui hubungan variabel konsentrasi pereaksi dengan aktifitas suatu obat termasuk didalamnya anti fungsi. Termasuk pula dalam hal ini adalah penentuan konsentrasi bahan anti jamur yang aktifitasnya memberikan efek setidak-tidaknya sama dengan kontrol positif.

Hal ini penting karena minyak atsiri adalah bahan yang diperoleh dengan proses yang cukup rumit dan panjang sehingga umumnya berharga mahal dan karenanya dengan mengetahui konsentrasi minimum yang memeberikan efek sama dengan kontrol positif tersebut akan memberikan pengetahuan yang berujung pada penggunaan minyak atsiri secara efektif dan efesien. Kontrol positif adalah suatu antifungi yang telah digunakan secara luas dan teruji. Berdasarkan latar belakang tersebut maka dilakukan penelitian tentang studi kinetika minyak daun cengkeh (Syzigium aromaticum) untuk antifungi Candida albicans.

\section{METODOLOGI}

\section{Bahan}

Bahan-bahan yang digunakan dalam penelitian ini adalah sampel daun cengkeh (Syzygium aromaticum), Escherichia coli, maltodekstrin, Amoxcillin, media NA, minyak tween, $\mathrm{MgSO}_{4} 2 \mathrm{H}_{2} \mathrm{O}$, akuades, alkohol $96 \%$, alkohol 70\%, kertas saring whatman, kain kasa, kapas steril, etanol dan aluminium foil.

\section{Alat}

Alat-alat gelas yang digunakan pada penelitian ini adalah piknometer, botol timbang, batang pengaduk, erlenmeyer, labu ukur, gelas kimia, corong, corong pisah, spatula, pipet volum, pipet tetes, botol vial, botol gelap, tabung reaksi. Alat-alat lainnya yang digunakan dalam penelitian ini adalah satu set alat destilasi uapair, kompor seribu mata, KG-SM (Kromatografi Gas-Spektrometri Massa), spray drying, refraktometer, inkubator, neraca analitik, autoklaf, waterbath, lemari pendingin, laminar air flow cabinet, shaker incubator, lampu UV, statif, klem, mistar, spidol, oven, vortex, pisau.

\section{Pengambilan dan Pengolahan Sampel Daun Cengkeh (Syzygium aromaticum)}

Daun cengkeh yang digunakan diambil dari daerah perkebunan cengkeh Desa Pusuea, Kecamatan Poleang Utara, Kabupaten Bombana, Sulawesi Tenggara. Selanjutnya sampel daun cengkeh kemudian dikeringkan selama empat hari. Proses pengeringan dilakukan pada suhu ruang tanpa terkena sinar matahari langsung. Pengeringan bertujuan untuk menguapkan sebagian air dalam daun cengkeh (Syzygium aromaticum) sehingga penyulingan berlangsung lebih mudah dan singkat. Pengeringan dilakukan Selama 4 hari dengan cara diangin-anginkan. Selanjutnya daun cengkeh diisolasi menggunakan seperangkat alat destilasi uap-air.

\section{Isolasi Minyak Daun Cengkeh dengan Menggunakan Destilasi Uap- Air \\ Proses isolasi dimulai dengan, daun cengkeh ditimbang sebesar $2 \mathrm{~kg}$ kemudian dimasukkan dalam wadah alat destilasi uap-air menggunakan pemanasan dengan kompor seribu mata. Daun Cengkeh yang akan disuling hanya akan terkena uap, dan tidak terkena air yang mendidih (Sastrohamidjojo, 2004). Proses destilasi uap-air dilakukan selama 4 jam. Destilat}


ditampung ke dalam wadah. Selanjutnya lapisan minyak cengkeh dan lapian air dipisahksan menggunakan corong pisah, kemudian ditambahkan $\mathrm{MgSO}_{4} \cdot 2 \mathrm{H}_{2} \mathrm{O}$ pada minyak cengkeh yang diperoleh untuk menghilangkan sisa air.

\section{Sterilisasi Alat dan Bahan}

Seluruh alat dicuci bersih dan dikeringkan. Botol vial, tabung reaksi, erlenmeyer, cawan petri dibungkus dengan kertas. Kemudian semuanya disterilkan dengan autoklaf pada suhu $121^{\circ} \mathrm{C}$ selama 15 menit. Pengerjaan aseptis dilakukan di dalam Laminar Air Flow yang sebelumnya telah dibersihkan dengan larutan alkohol $70 \%$, lalu disterilkan dengan lampu $U V$ yang dinyalakan selama kurang lebih 1 jam sebelum digunakan dalam uji antijamur (Risnawati, 2017).

\section{Peremajaan Jamur Candida albicans dalam Media Padat (PDA)}

Media PDA dibuat dengan cara menimbang 0,2 gram dextrosa dan 0,4 gram agar dimasukkan kedalam erlenmeyer, kemudian ditambahkan 20 $\mathrm{mL}$ kaldu kentang dan diaduk hingga homogen. Setelah homogen erlenmeyer ditutup dengan kasa dan kapas (disumbat) kemudian diautoklaf pada tekanan $121 \mathrm{Mpa}$. Media PDA yang telah dibentuk diletakkan dalam Laminar air flow dan disinari sinar Ultra Violet (UV) selama beberapa menit. $20 \mathrm{~mL}$ media PDA dimasukkan dalam tabung reaksi, kemudian tabung reaksi dimiringkan hingga memadat dan digoreskan 1 ose jamur C.albicans dalam media PDA pada tabung reaksi, lalu tabung reaksi ditutup dengan kasa dan kapas kemudian diinkubasi selama $3 \times 24$ jam pada suhu $37^{\circ} \mathrm{C}$ (Hidayatullah, 2012).

\section{Peremajaan Jamur Candida albicans dalam Media Cair}

Membuat media cair dengan menimbang 0,1 gram dekstrosa dan dimasukkan dalam botol vial. Setelah dimasukkan dalam botol vial ditambahkan $10 \mathrm{~mL}$ kaldu kentang kemudian diaduk hingga homogen. Setelah diaduk, botol vial ditutup dengan kasa dan kapas (sumbat) kemudian diautoklaf pada tekanan $121 \mathrm{Mpa}$. Media cair yang telah terbentuk diletakkan pada laminar air flaw dan disinari sinar $U V$ selama beberapa menit. Digoreskan 1 ose jamur C.albicans dalam media cair dalam botol vial kemudian botol vial ditutup dengan kasa dan kapas (sumbat) dan diinkubasi selama $3 \times 24$ jam pada suhu $37^{\circ} \mathrm{C}$ (Bangjavicenna, 2008).

\section{Uji Aktivitas Antijamur Candida albicans}

Medium PDA dipipet sebanyak $20 \mathrm{~mL}$, kemudian dimasukkan dalam tabung eppendorf dan ditambahkan $10 \mu \mathrm{L}$ inokulum jamur $C$. albicans lalu dikocok hingga homogen. Setelah homogen dituang dalam cawan petri dengan gerakan memutar hingga media merata pada permukaan cawan petri, lalu didiamkan beberapa menit hingga memadat. Kemudian diletakkan kertas cakram (diameter $0,5 \mathrm{~cm}$ ) yang telah direndam dalam larutan uji (Minyak daun cengkeh dalam konsentrasi $100 \%, 75 \%, 50 \%$, $25 \%$ ), kontrol positif (ketokonazol 2\%), kontrol negatif (minyak tween) pada permukaan media agar yang telah memadat. Setelah itu, cawan petri ditutup dengan rapat dan dibungkus dengan plastik wrap. Kemudian diinkubasi selama 3x24 jam dalam suhu ruang dan diukur zona hambat yang terbentuk (Risnawati dkk., 2017).

\section{Pengolahan dan Analisis Data}

Data yang diperoleh adalah ukuran besarnya zona bening yang dihasikan dalam uji antijamur yang menggunakan pendekatan regrase linear namun diturunkan dari persamaan kinetika kimia dengan bentuk umum (Firmana dan Tjahjani, 2004):

$$
\mathrm{r}=k[\mathrm{~A}]^{\mathrm{n}}
$$

Keterangan : $\mathrm{r}=$ Laju, $k=$ Konstanta laju reaksi, $[\mathrm{A}]=$ Kosentrasi zat, $\mathrm{n}=$ Orde reaksi.

Besarnya laju dapat ditentukan dengan $r=$ zona bening $(\mathrm{zb}) /$ waktu inkubasi $(\mathrm{t})$; namun karena $t$ merupakan waktu inkubasi yang besarnya konstan maka dapat dipandang bahwa laju identik dengan zona bening. Berdasatkan persamaan tersebut, dengan menghitung nilai logaritmanya maka akan diperoleh bentuk persamaan regresi linear:

$$
\log \mathrm{r}=\log k+\mathrm{n} \log [\mathrm{A}]
$$

identik dengan persamaan:

$$
\log \mathrm{zb}=\log k+\mathrm{n} \log [\mathrm{A}]
$$

persamaan ini merupakan bentuk persamaan garis lurus dengan bentuk umum: $y=a+b x$ 
maka dari persaman tersebut jika dibuat plot hubungan $\log [\mathrm{A}]$ sebagai sumbu $\mathrm{x}$ terhadap log zb sebagai sumbu y maka akan diperoleh :

$$
\begin{aligned}
& \text { intersep } \mathrm{a}=\log k \text { maka } k=10^{\mathrm{a}} \\
& \text { slope } \mathrm{b}=\mathrm{n}=\text { orde }
\end{aligned}
$$

\section{HASIL DAN PEMBAHASAN}

\section{Ekstraksi minyak cengkeh}

Minyak cengkeh diperoleh melalui proses destilasi uap air yaitu proses hidrodifusi dimana uap air akan masuk kedalam jaringan sel tanaman yang menyebabkan pecahnya dinding sel tanaman sehingga minyak yang terkandung didalamnya akan terdorong keluar. Campuran uap air dan minyak cengkeh akan mengalir ke kondensor sehingga terjadi pengembunan dan dihasilkan destilat. Ciri khas model ini adalah uap selalu dalam keadaan basah, jenuh, dan tidak terlalu panas. Bahan tanaman yang akan disuling hanya berhubungan dengan uap dan tidak dengan air panas.

Proses hidrodifusi terjadi ketika suhu air mendidih, sebagian minyak yang mudah menguap larut dalam air ini berdifusi ke luar dengan peristiwa osmosis, melalui selaput membran yang sedang mekar sampai dipermukaan bahan, dan selanjutnya menguap oleh uap yang dilewatkan ke kondensor. Proses ini berlangsung terus menerus hingga semua senyawa yang mudah menguap terdifusi dari kelenjar-kelenjar minyak dan kemudian teruapkan oleh air yang lewat (Sastrohmidjojo, 2004). Destilat kemudian ditampung lalu air dan minyak dipisahkan sehingga diperoleh minyak atsiri daun cengkeh. Minyak atsiri kemudian dimurnikan lagi dengan diberi $\mathrm{MgSO}_{4}$ agar air yang masih ada benar-benar habis, akhirnya diperoleh minyak atsiri murni dari daun cengkeh dengan perhasil sekitar $4,2 \%$ berat kering daun cengkeh.

\section{Hasil Uji Aktifitas Antifungi}

Aktivitas antifungi minyak daun cengkeh menggunakan metode difusi cakram steril. Pengujian menggunakan ketokonazol sebagai kontrol positif dan minyak tween sebagai kontrol negatif. Ketokonazol sebagai kontrol positif dipilih karena merupakan antijamur berspektrum luas golongan imidazol yang bekerja dengan menghambat biosintesis ergosterol yang merupakan komponen penting dari pembentukan membran sel jamur. Ketokonazol menghambat enzim cytochromp 450 yang menyebabkan akumulasi 14-alfa-methylsterol yang tidak dapat menggantikan fungsi ergosterol membran sel jamur. Penurunan ergosterol membran sel jamur menyebabkan rusaknya permeabilitas membran, akibatnya sel jamur kehilangan komponen intraselulernya. Mekanisme seperti itulah yang dipakai ketokonazol dalam menghambat pertumbuhan jamur $C$.albicans (Jawetz et al., 1995). Adapun Minyak tween sebagai kontrol negatif berperan sebagai emulgator antara minyak nilam dan media PDA.

Media PDA merupakan media yang cocok untuk digunakan untuk pertumbuhan jamur. Media ini mengandung nutrisi yang dibutuhkan oleh jamur yaitu potato (kentang), dextrose dan agar. Kentang yang terdapat dalam media PDA dapat mempercepat proses sporulasi dan pigmentasi bagi jamur. Disamping itu juga mengandung antibiotik yang dapat menghambat pertumbuhan bakteri, sehingga diharapkan tidak terjadi kontaminasi oleh bakteri dan hanya jamur saja yang dapat tumbuh didalammnya.

Hasil analisis uji aktivitas antifungi minyak daun cengkeh dalam menghambat pertumbuhan jamur $C$. albicans dilihat pada Gambar 1 .

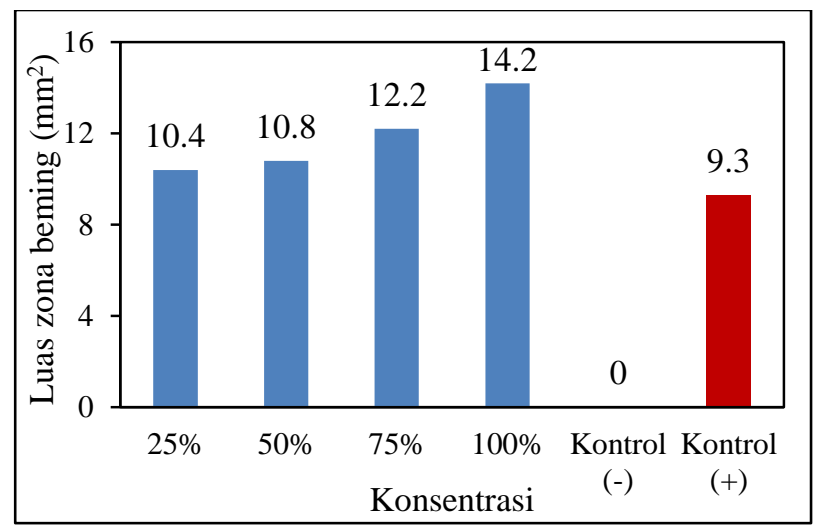

Gambar 1. Hasil uji antifungi minyak daun cengkeh dalam menghambat pertumbuhan jamur C. albicans

Gambar 1 memperlihatkan aktivitas ketokonazol sebagai kontrol postif lebih kecil dibandingkan aktivitas minyak daun cengkeh. Berdasarkan data tersebut juga terlihat perbedaan aktifitas antifungi tiap-tiap variasi konsentrasi minyak daun cengkeh yang berbeda-beda yakni berturut-turut konsentrasi 25; 50, 75 dan 100\% dengan luas zona bening berturut-turut 10,$4 ; 10,8 ; 12,20$ dan $14,2 \mathrm{~mm}^{2}$, 


\section{Rustam Musta dkk. / Indo. J. Chem. Res., 2019, 6(2), 107-114}

memperlihatkan bahwa terdapat peningkatan zona bening seiring bertambahnya konsentrasi minyak daun cengkeh. Konsentrasi 100\% minyak daun cengkeh emerikan rata-rata diameter zona bening tertinggi sebesar 14,2 $\mathrm{mm}^{2}$. Menurut Mbatu dkk., (2018) diameter zona bening 11-20 $\mathrm{mm}$ memberikan respon hambatan pertumbuhan kuat. Dengan demikian aktifitas antifungi minyak daun cengkeh pada penelitian ini memberikan respon daya hambat kuat pada konsentrasi $75 \%$ dan $100 \%$ serta daya hambat kategori sedang untuk konsentrasi $25 \%$ dan $50 \%$.

Minyak daun cengkeh dapat menghambat pertumbuhan jamur $C$. albicans disebabkan adanya senyawa fenol dan asam-asam organik yang terkandung didalam fraksi hasil pirolisis. Mekanisme senyawa fenol sebagai antifungi yaitu dengan cara mendenaturasi ikatan protein pada membran sel, sehingga membran sel menjadi lisis dan senyawa fenol dapat masuk ke dalam inti sel. Hal ini dapat menghambat pertumbuhan jamur bahkan akan mati (Sulistiyawati dan Mulyati 2009). Senada dengan itu, Siswandono dan Sukardjo (1995) menyatakan bahwa mekanisme senyawa fenol dalam menghambat pertumbuhan fungi yaitu dengan cara berinteraksi dengan dinding sel fungi, dimana pada kadar yang rendah akan mendenaturasi protein dan pada kadar yang tinggi akan menyebabkan koagulasi protein sehingga sel akan mati (Siswandono dan Sukardjo,1995). Menurut Sulistiyawati dan Mulyati (2009) dalam Putu (2016) senyawa fenol berfungsi sebagai antijamur karena ion $\mathrm{H}^{+}$fenol dapat menyerang gugus polar (gugus fosfat) pada fosfolipid membran sel jamur seperti $C$. albicans sehingga fosfolipid akan terurai. Hal tersebut menyebabkan fosfolipid tidak dapat mampu mempertahankan bentuk membran sel, akibatnya membran akan bocor dan jamur akan mengalami penghambatan pertumbuhan bahkan akan mati.

Selain senyawa fenol, asam organik juga berperan dalam menghambat aktivitas jamur seperti jamur C.albicans. Asam organik adalah asam lemah, yang berarti bahwa proporsi molekul tertentu tetap tidak terdisosiasi, bergantung pada nilai $\mathrm{pKa}$ asam dan tingkat $\mathrm{pH}$ sekitar. Molekul tak beraturan yang tidak terkoordinasi ini melewati membran sel ke mikroorganisme dengan lebih mudah. Saat berada dalam sel mikroba, asam melepaskan protonnya $\left(\mathrm{H}^{+}\right)$di lingkungan alkalin yang lebih basa dari sitoplasma, sehingga terjadi penurunan $\mathrm{pH}$ intraselular jamur. Ini mempengaruhi metabolisme mikroba, menghambat aksi enzim penting mikroba. Sel jamur dipaksa mengeluarkan energi untuk mengeluarkan proton, yang menyebabkan akumulasi anion asam intraselular, tergantung pada gradien $\mathrm{pH}$ di seluruh membran. Anion di dalam sel mikroba diperkirakan mengganggu proses metabolisme dalam sel (Luckstadt dkk., 2014 dalam Rahadi, 2017).

\section{Kinetika Minyak Daun Cengkeh (Syzigium aromaticum) sebagai Antifungi Candida albicans}

Kajian kinetika minyak daun cengkeh (Syzigium aromaticum) sebagai antifungi Candida albicans dilakukan setelah mengukur zona bening tiap-tiap konsentrasi yang telah ditentukan yakni 25\%, 50\%, 75\% dan $100 \%$. Hasil pengukuran zona bening tiap-tiap konsentrasi tersebut dapat diperlihatkan pada Gambar 2.

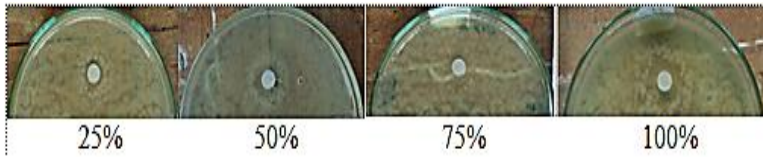

Gambar 2. Zona bening tiap-tiap konsentrasi

Konsentrari minyak daun cengkeh (Syzigium Aromaticum) minimum yang efektif untuk antifungi Candida albicans ditentukan dengan lebih dahulu menentukan orde dan tetapannya menggunakan persaamaan regresi linear yang diturunkan dari persamaan kinetika kimia. Analisis mengunakan regresi linear tersebut menghasilkan grafik sebagai mana ditunjukkan pada Gambar 3.

Gambar 3 memperlihatkan hubungan variabel $\mathrm{x}$ yaitu nilai logaritma konsentrasi minyak daun cengkeh (\%) dengan variabel y yaitu luas zona bening $(\mathrm{mm})$. Hasil perhitungan memberikan nilai $\mathrm{a}=0,7041$ dan $\mathrm{b}=0,2112$ dengan nilai $r^{2}=0,8175$ yang berarti bahwa kedua variabel berkorelasi positif dan masuk kategori sangat kuat. selanjutnya nilai tetapan aktifitas dapat ditentukan dengan menggunakan rumus $10^{\mathrm{a}}=10^{0,7041}=5,0594$. Nilai tetapan aktifitas tersebut berlaku untuk aktifitas minyak daun cengkeh pada antifungi Candida albicans yang waktu inkubasinya 3 hari atau 72 jam pada 
Rustam Musta dkk. / Indo. J. Chem. Res., 2019, 6(2), 107-114

temperatur $37^{\circ} \mathrm{C}$. Adapun orde rekasinya $(n)=$ 0,2112 . Orde yang diperoleh merupakan pecahan yang nilainya terletak antara nol dan satu.

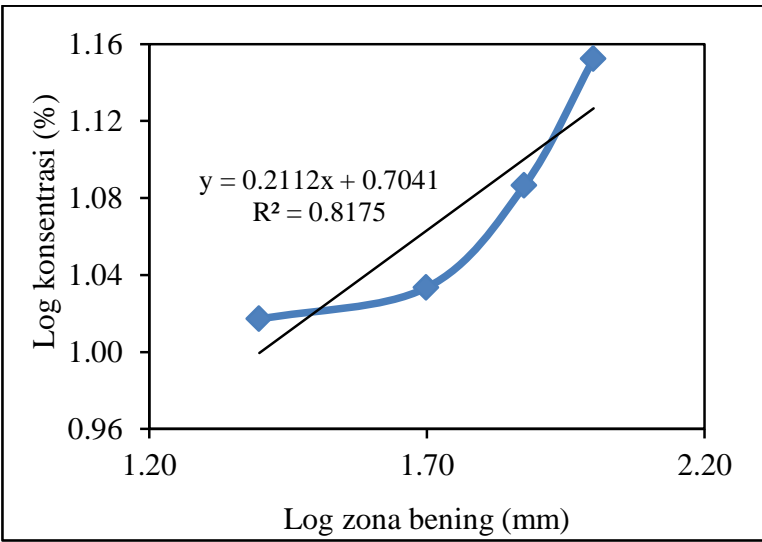

Gambar 3. Plot log konsentrasi terhadap log zona bening

Prayitno (2007) menyatakan bahwa orde reaksi dapat berupa bilangan bulat positif, nol atau pecahan. Orde sebesar 0,2112 juga menandakan bahwa ada peningkatan aktifitas antifungi (zona bening) sebagai akibat peningkatan konsentrasi minyak daun cengkeh karena orde tidak tepat nol namun peningkatan tersebut juga tidak berbanding lurus dengan konsentrasi minyak daun cengkeh. Petrucci (1992) menyatakan bahwa untuk reaksi berorde nol maka laju pereaksi tidak bergantung pada konsentrasi pereaksi sama sekali. Sementara itu, Keenan (1984) mengemukakan bahwa jika laju suatu reaksi kimia berbanding lurus dengan pangkat satu konsentrasi dari hanya satu pereaksi maka reaksinya merupakan orde satu.

Berdasarkan nilai orde dan tetapan $(\mathrm{k})$ yang telah diketahui maka dapat ditentukan hubungan variabel konsentrasi setiap saat $\left(A_{t}\right)$ dengan konsentrasi mula-mula $\left(\mathrm{A}_{\mathrm{o}}\right)$ dan waktu $(\mathrm{t})$.

$$
\begin{aligned}
& r=k \cdot[A]^{0,2112} \\
& -\frac{\partial A}{\partial t}=k A^{0,2112} \\
& -\frac{\partial A}{A^{0,2112}}=k \cdot \partial t \\
& -\int \frac{\partial A}{A^{0,2112}}=\int k \cdot \partial t \\
& -\int \frac{1}{A^{0,2112}} \partial A=\int k \cdot \partial t
\end{aligned}
$$

$$
\begin{aligned}
& -\int A^{-0,2112} \partial A=k . t \\
& -\left[\frac{1}{0,7888} A_{t}{ }^{0,7888}-\frac{1}{0,7888} A_{0}^{0,7888}\right]=k t \\
& \frac{1}{0,7888} A_{0}{ }^{0,7888}-\frac{1}{0,7888} A_{t}{ }^{0,7888}=k t \\
& \frac{1}{0,7888}\left[A_{0}^{0,7888}-A_{t}^{0,7888}\right]=k t
\end{aligned}
$$

Oleh karena nilai $k=5,0594$ maka:

$$
\frac{1}{0,7888}\left[A_{0}^{0,7888}-A_{t}^{0,7888}\right]=5,0594 t
$$

Jika: $k^{\prime}=k \times 0,7888=5,0594 \times 0,7888=3,99$ maka:

$$
\begin{aligned}
& A_{0}^{0,7888}-A_{t}{ }^{0,7888}=k^{\prime} \cdot t \\
& A_{t}{ }^{0,7888}=A_{0}{ }^{0,7888}-k^{\prime} \cdot t \\
& A_{t}{ }^{0,7888}=A_{0}{ }^{0,7888}-3,99 . t
\end{aligned}
$$

Apabila $0,7888 \approx 0,8$ dan $3,99 \approx 4$ maka diperoleh hubungan yang lebih sederhana yaitu:

$$
\mathrm{A}_{\mathrm{t}}^{0,8}=\mathrm{A}_{\mathrm{o}}^{0,8}-4 \mathrm{t}
$$

Sehingga besarnya konsentrasi minyak daun cengkeh untuk antifungi Candida albicans yang aktifitasnya sama dengan kontrol positif yaitu 9,3 mm seperti ditunjukkan pada Gambar 1, dapat dihitung dengan persamaan berikut ini:

$$
\begin{aligned}
& 9,3=5,0594[\mathrm{~A}]^{0,2112} \\
& {[\mathrm{~A}]^{0,2112}=\frac{9,3}{5,0594}} \\
& {[\mathrm{~A}]=(1,8382)^{1 / 0,2112}} \\
& {[\mathrm{~A}]=17,86}
\end{aligned}
$$

Berdasarkan hasil perhitungan yang diperoleh di atas dapat dihitung nilai konsentrasi minyak daun cengkeh dengan aktifitas yang sama dengan kontrol positif dan diperoleh $17,86 \%$. Hal ini memperlihatkan bahwa agar diperoleh aktifitas yang sama dengan kontol positif atau aktifitas bahan minyak daun cengkeh (Syzigium aromaticum) minimum yang efektif untuk antifungi Candida albicans maka setidaktidaknya harus digunakan konsentrasi sebesar $17,86 \%$. 


\section{KESIMPULAN}

Berdasarkan hasil penelitian maka dapat disimpulkan bahwa aktivitas antifungi minyak daun cengkeh (Syzigium aromaticum) pada Candida albicans berbeda untuk tiap variasi konsentrasi $100 \%, 75 \%, 50 \%$ dan $25 \%$ yakni berturut-turut sebesar $14,2 \mathrm{~mm}^{2}, 12,2 \mathrm{~mm}^{2}, 10,8$ $\mathrm{mm}^{2}$ dan $10,4 \mathrm{~mm}^{2}$. Orde reaksi antifungi minyak daun cengkeh (Syzigium aromaticum) pada Candida albicans sebesar 0,2112 dengan $\mathrm{k}$ $=5,0594$. Hubungan variabel konsentrasi minyak daun cengkeh (Syzigium aromaticum) setiap saat $\left(A_{t}\right)$ dengan konsentrasi minyak daun cengkeh (Syzigium aromaticum) mula-mula $\left(\mathrm{A}_{\mathrm{o}}\right)$ dan waktu (t) diberikan oleh persamaan: $\mathrm{A}_{\mathrm{t}}^{0,8}=\mathrm{A}_{\mathrm{o}}^{0,8}$ 4 t. Konsentrasi minyak daun cengkeh (Syzigium aromaticum) minimum yang efektif untuk antifungi Candida albicans sebesar 17,86\%.

\section{DAFTAR PUSTAKA}

Bangjavicenna, E., 2008, Potensi Propolis Lebah Trigona spp sebagai Bahan Antimikroba Ketombe. Skripsi, Program Studi Biokimia. Fakultas Matematika dan Ilmu Pengetahuan Alam Institut Pertanian Bogor, Bogor.

Charles, D.J., 2013, Clove in Antioxidant Properties of Spices Herbs and Other Sorces, Springer, New York (US).

Firmana, A.A.N., Thjahjani, S, 2014, Karakterisasi Hasil dan Penentuan Laju Reaksi Fermentasi Bonggol Pisang (Musa paradisiaca) Menjadi Etanol dengan Saccharomyces cerevisiae, UNESA Journal of Chemistry, 3(3), 21-26.

Hasan, M.N., 2015, Pengaruh Ekstrak Rimpang Jeringau (Acorus calamus L) dalam Beberapa Pelarut Organik Terhadap Aktivitas Antioksidan dan Antifungi Secara In Vitro, Skripsi, Fakultas MIPA, Universitas Islam Negeri, Malang.

Hidayatullah, M., 2012, Uji Daya Antifungi Minyak Atsiri Bawang Merah (Allium ascalonicum L) Terhadap Candida albicans ATCC 10231 Secara In Vitro, Skripsi. Fakultas Kedokteran.Universitas Muhammadiyah Surakarta. Surakarta.

Jawetz, M., Adelberg S., 2001, Mikrobiologi Kedokteran. Edisi I. Salemba Medika. Jakarta.

Keenan, W.C., Klenfelter, D.C, Wood, J.H, 1984, Kimia untuk Universitas, Alih
Bahasa: Pujaatmaka, A.H. Erlangga, Jakarta.

Khafidhoh, Z., Dewi, S.S., Iswara, A., 2015, Efektivitas Infusa Kulit Jeruk Pururt (Citrus hystrix DC.) terhadap Pertumbuhan Candida albicans Penyebab Sariawan secara In Vitro, Publikasi Ilmiah, Universitas Muhammadiyah Semarang: Semarang, 31-37.

Kim, L.S., Yang, M.R., Lee, O.H., Kang, S.N., 2011, Antioxidant Activities of Hot Water Extract from Various Species, International Jurnal of Molecular Science, 12, 41204131.

Mbatu, S. R.T., Putu B.K., Gede Y.S., Rita, W. S., 2018, Aktivitas Minyak Atsiri Daun Cengkeh Sebagai Antijamur Terhadap Candida albicans, Jurnal Media Sains, 2(1), 61-65.

Pelezar, M.J. Chan, S., 2007, Dasar-Dasar Mikrobiologi 2, UI Press, Jakarta.

Prayitno, 2007, Kajian Kinetika Kimia Model Matematik Reduksi Kadmium Melalui Laju Reaksi, Konstanta dan Orde Reaksi dalam Proses Elektrokimia, Ganendra, 10(1), 2734.

Putu, N.L.P.A., 2016, Uji Aktivitas Antifungi Minyak Atsiri Daun Sirih Hijau (Piper betle L.) dari Daerah dengan Variasi Ketinggian Tempat Tumbuh Di Bali Terhadap Fungi Candida albicans Atcc 10231 dengan Menggunakan Metode Difusi Disk, Skripsi, Universitas Udayana. Denpasar.

Salni, Aminasih, N., Sriviona, R., 2013, Isolasi Senyawa Antijamur dari Rimpang Lengkuas Putih (Alpinia galanga (L.) Willd) dan Penentuan Konsentrasi Hambat Minimum Terhadap Candida albicans, Prosiding Semirata FMIPA, Universitas Lampung, Lampung.

Triyono, Setiaji, B., Tahir, I., 1998, Buku Ajar Kinetika Kimia, Jurusan Kimia, FMIPA. UGM, Jogjakarta.

Rahadi, S., 2017, Acidifier sebagai Feed Aditif, Agripreneurship.com. Diakses tanggal 31 Juli 2018.

Petrucci, R.H., 1992, Kimia Dasar, Prinsip dan Terapan Modern, Editor Penerjemah, Suminar Achmadi. Erlangga, Jakarta.

Putri, R.L., Hidayat, N., Rahmah, N.L., 2014, Pemurnian Eugenol dari Minyak Daun Cengkeh dengan Reaktan Basa Kuat $\mathrm{KOH}$ 
Rustam Musta dkk. / Indo. J. Chem. Res., 2019, 6(2), 107-114

dan $\mathrm{Ba}(\mathrm{OH})_{2}$ (Kajian Konsentrasi Reaktan), Industria: Jurnal Teknologi dan Management Agroindustri, 3 (1), 1-12.

Risnawati. Nurliana, L., Kurniawati, D., 2017, Mikroenkapsulasi Minyak Atsiri dari Tanaman Nilam (Pogostemon cablin Benth) Sebagai Antijamur Candida albicans, Indo. J. Chem. Res., 4(2), 386-393.

Sastrohamidjojo, H., 2004, Kimia Minyak Atsiri, Gajah Mada University Press, Yogyakarta.

Siswandono Soekarjo, B., 1995, Kimia Medisinal, Universitas Airlangga Press, Surabaya.
Sulistyawati, D., Mulyati, S, 2009, Uji Aktivitas Antijamur Infusa Daun Jambu Mete (Anacardium occidentale L.) terhadap Candida albincas, Biomedika, (2) 47-51.

Widyanigrum, T., Wahyuni, T., 2015, Uji Aktivitas Antifungi Ekstrak Etanol Daun Sidaguri (Sida rhombifolia) Terhadap Candida albicans, Prosiding, Seminar Nasional Pendidikan Biologi Universitas Muhamadiyah Malang, 377-385. 